University of Rhode Island

DigitalCommons@URI

Open Access Master's Theses

1957

\title{
Aspects of the History of Westerly During the Civil War
}

Robert F. Shea

University of Rhode Island

Follow this and additional works at: https://digitalcommons.uri.edu/theses

\section{Recommended Citation}

Shea, Robert F., "Aspects of the History of Westerly During the Civil War" (1957). Open Access Master's Theses. Paper 720.

https://digitalcommons.uri.edu/theses/720

This Thesis is brought to you for free and open access by DigitalCommons@URI. It has been accepted for inclusion in Open Access Master's Theses by an authorized administrator of DigitalCommons@URI. For more information, please contact digitalcommons-group@uri.edu. 
ASPECTS OF THE HISTORY

OF WESTERLY DURING THE CIVIL WAR

BY

ROBERT F. SHEA

A THESIS SUBMITTED IN PARTIAL FULFILLMENT OF THE REQUIREMENTS FOR THE DEGREE OF

MASTER OF ARTS

IN

HISTORY

UNIVERSITY OF RHODE ISLAND

1957 


\section{MASTER OF ARTS THESIS \\ OF}

ROBERT F. SHEA

Approved:

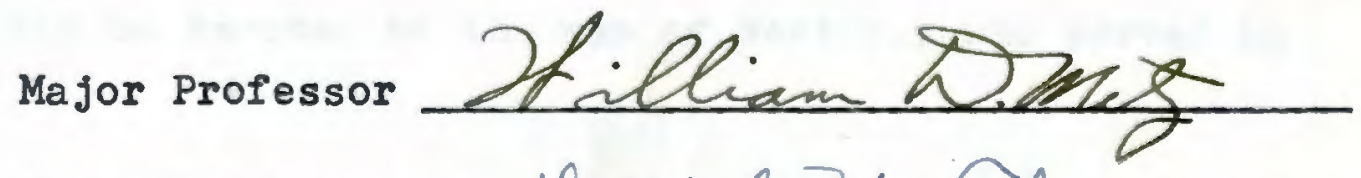

Head of Department Laweel P. Powas

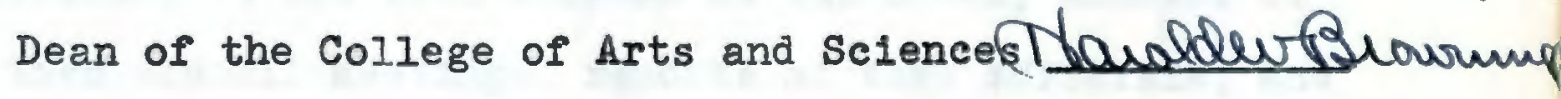

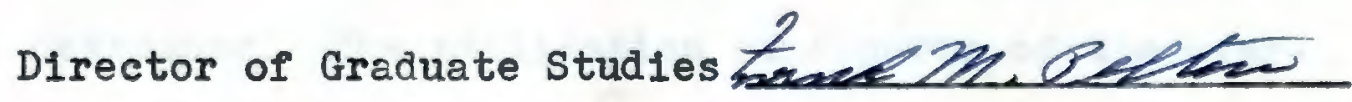

UNIVERSITY OF RHODE ISLAND

1957 


\section{ABSTRACT}

The object of this study 18 to ascertain from arailable sources the effect of the C1vil War on Westerly, Rhode Island. Partioular attention was pald to economic aspects of the life of the town. Every war has some effect on the towns and c1t1zens of the countries involved, but this effect is not always permanent. Permanent results were hard to demonstrate, but temporary results are oftentimes as important as permanent ones and these could not be neglected.

Because it is diffcult to eliminate the human element during such trying periods as wars, the author felt that some space should be devoted to the men of Westerly who served in the war.

To 1llustrate the economic effects of the war on the town It was necessary to use such sources as tax books, minutes of town and town councll meetings, roports of town offlcials, and the local newspaper. The utilization of reports of the overseer of the poor and the Relief Committee helped to give some understanding of the job opportunities of the period. A constant problem in developing this tnesis was the lack of individual or industrial business records to substantiate assumptions developed by reading avallable sources. However, by using the comparative abundance of material on Rowse Babcock, a businessman of the period, a fairly olear ploture of general economic activity was probably obtalned. 
Research for the paper turned up a large amount of data on Watch Hill which today is an Important part of the Westerly community. Because it was quite obvious that Watch Hill business increased appreciably during the Civil War the author decided to incorporate a chapter on this section of the town in the paper.

The conclusions of the thesis were satisfying and at the same time disappointing. It was obvious that during the early stages of the war the volunteers were mainly young or poor men. A detalled description of the bounties offered during the war was obtained and proved very enlightenting. Westerly's tox rate increased appreclably during the war. Substantial proof was found that Watch Hill received major impetus toward becoming a famous resort spot during the Civil War. Conclusive proof of the economic effect of the war on Westerly proved to be the trouble-spot of the thesis because of the previously mentioned absence of data. 
TABLE OF CONTENTS

Chapter

I. WESTERLY AT THE OUTBREAK OF THE CIVIL WAR......2

II. THE WESTERLY RIFLES..................8

First Regiment, Rhode Island Volunteers Captain Card Armory Hall

III. THE DRAFT..........................19

Recruiting for Volunteors

The Draft of March, 1863

Succeeding Drafts

IV. BOUNTIES TO SOLDIERS AND AID TO THEIR FAMILIES3I

Early Bounties

Increase in Bounties

Relief Committee and Overseer of the Poor

V. ECONOMIC EFHECT OF THE WAR.............4l

Rise in the cost of Government

Rowse Babcock III

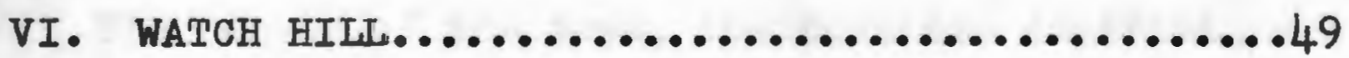

George Nash and the Watch H1ll House

Westerly People Visit Watch Hill

Excursion Boats to Watch Hill

Now Hotels and Cottages Built

VII. CONCLUSIONS......................57

APPENDIX............................60

BIBLIOGRAPHY.....................66 


\section{CHAPTER I}

WESTERLY AT THE OOTBREAK OF THE CIVIL WAR

In the 1850's Westerly was a small village stretched along the banks of the Pawcatuck River. The river separated the states of Rhode Island and Connecticut and gave access to the Atlantic Ocean about five miles distant.

The total number of Westerly inhabitants in 1860 was 3,469. I The only densely populated sections were on Main, High, and Broad streets. The main industries of the village were a few small mills and machine shops and two shipyards. On the west side of the river was the smaller village of Pawcatuck in the Town of stonington, Connecticut. The homes on this side were located mainly on West Broad and Mechanic streets. As the roads fanned out from these areas houses were located farther and farther apart. ${ }^{2}$

The center of the town, the business district, was near the bridge spanning the river. It was here that Stillman and Potter kept drug store where people could buy the "cure-alls" of that period. Above the drugstore was the furniture and undertaking establishment of Clark and Dentson. In the same building life and fire insurance was sold by Henry W. Stiliman. E. P. Hitchcock for a time sold the latest styles of millinery

1861.2

1 The Narragansett Weekly (Westerly, R. I.), September 19, Albert P. Pendleton, "Westerly in the Fifties" (unpublished manuscript in the Local History file in the westerly Public Library), pp. $1-3$. 
to the women and Elisha Barnes sold most of the periodicals of the day in his store. George Wells maintained a tannery on Main street and Elam Gates served as a painter and paper hanger. ${ }^{3}$ At the west end of the Pawcatuck bridge was the 0. M. Stillman store, Mealer in School, Hiscellaneous and Blank Books, Toys and Fancy Articles; .... 14 These were only a few of the estimated three dozen establishments that served the people of Westerly.

The taxes in 1860 amounted to fifteen cents on every $\$ 100$ of assessed property. 5

At this time, and for some years later, the town was served by one newspaper named The Narragansett Weekly. Published every Thursday, this paper kept the people of Westerly as up to date as possible with current news besides supplying them with fiction and a bit of homely philosophy. Most of the business establishments adrertised in this publication.

The town was fortunate in being located on the main line of the Providence and Stonington rallroad which first began operations in November, 1837. This afforded the townspeople fairly good transportation facilities. However, until the late 1850's the line ended at Stonington and it was

3Pendleton, "Westerly in the Fifties," pp.4-5.

4The Narragansett Weekly, passim, 1855-1860.

5Ibid., June 12, 1862. 


\section{$-4-$}

then necessary to take boat passage either directly to New York or to New London where the rallroad service resumed, this time uninterrupted, to New York. In 1859 an extension was built between Stonington and New London which made the final link in continuous railroad service between Boston and New York. 6

Ontil the completion of this connecting line most of the goods sold in the village stores and used in the various industries were brought in by water. Schooners and sloops with low drafts came up the Pawcatuck River almost daily and docked at Westerly. These boats delivered goods from such cities as New York, New Heven, Providence, and Newport.7 The shipbuilding industry in Westerly was carried on primarily by two companies: Silas Greenman and Son on the Westerly side of the river and H. F. Sheffield in Pawcatuck. The ships built ranged in cargo capacity from thirty to eight hundred tons, and many of them salled all over the world. The launching of a large ship was a festive occasion and was often attended by the people of the village. The last vessel built by the Sheffields was a three-masted schooner launched in 1856, but the Greenmans continued to build ships until $1874 .^{8}$

In 1855 the firm of Cottrell and Babcock was founded in

6Pendleton, "Westerly in the Fifties,"pp. 9-13.

TThe Narragansett Weekly, passim, 1855-1858.

${ }^{8}$ Pendleton, "Westerly in the Fifties," pp.22-26. 
Pawcatuck. The owners were Calvert B. Cottrell and Nathan Babcock. The firm manufactured printing presses and cotton machinery and in 1858 employed around thirty men. 9 Their printing presses were destined to become famous throughout the country.

The granite industry for which Westerly became noted was still young in the days preceding the war. Orlando Smith originally developed the Westerly granite industry, and when he died in 1859 the business was taken over by William A. Burdick and William C. Pendleton. 10 The stone was used in local building but did not come into wide use until a later period. An example of local utilization was the protective wall built around the lighthouse at Watch Hill in 1858. The Onited states spent $\$ 40,000$ in bullding this structure and Orlando Smith supplied all of the stone used.Il

In the 1850's Watch Hill, located near the mouth of the Pawcatuck, was only a small settlement with not more than 2 half dozen houses. One of its chief attractions was its excellent fish and lobster dinners which cost twenty-five cents. Ont1l 1856 there was only one public hotel at the spot and most patronizers were middle-aged people looking for a rest. The general vicinity, however, was popular with Westerly

9The Narragansett Weekly, September 30, 1858. 10pendleton, wWesterly in the Fifties," pp. 19-22. IIThe Narragansett Weekly, July 1, 1858. 
citizens for one-day outings and pienies. 12

Politically speaking, Westerly was simllar to many other northern villeges during this period. Interest in abolitionist movements was very evident in the spring and summer of 1858. An article in the May 6 issue of The Narragansett Weekly relates in very partisan language the story of an unsuccessful attempt to capture an escaped Negro slave.13 On May 20 the Seventh Day Baptist Eastern Association held a meeting In Hopkinton and passed a resolution denouncing slavery. 14 In August anti-slavery feeling was evinced in an editorial in the local newspaper concerning emancipation of Negroes in Jamaica. 15 In late August, 1858, a man named Howland started a series of anti-slavery meetings in Westerly and the sessions lasted until september 6.16

The semi-political organization known as the Wide Awekes spread to Westerly in 1860.17 Besides being pro-Republican in the campaign of that year the organization had ant1foreigner sentiments. Members carrying torches and singing songs did a great deal of marching through the city streets.

12 Pendleton, "Westerly in the Fifties," p.25.

13 The Narragansett Weekly, May 6, 1858.

14 Ib1d., May 27, 1858.

${ }^{15}$ Ibid., August 5, 1858.

${ }^{16}$ Ibid., September 9, 1858.

17 Frederic Denison, Westerly and Its Witnesses (Providence: J.A. \& R.A. ReId, 1878), p.215. 
They also joined in out-of-town celebrations in Providence, Stonington, New London, and Norwich. 18

A counterpart of Westerly could have been found in ans section of the costal Northeast. Her men were primarily engaged in fishing and farming, although industry was beginning to make inroads into these occupations. Like those from other areas, the men of Westerly would soon spill their life blood while fighting for the Union cause. 


\section{CHAPTER II}

\section{THE WESTERLY RIFLES}

First Regiment, Rhode Island Volunteers

On April 12, 1861, the forces of the seceded southern states bombarded Fort Sumter. This action plunged the United States of America into a civil war which was to have far-reaching effects and repercussions. On Apr11 15, recognizing the gravity of the situation, President Iincoln issued a call for 75,000 militia from "several states of the Onion, nI

Governor William Sprague of Rhode Island proclaimed a special session of the General Assembly for April 17 to act upon the President's call for men. At this session an act was passed to furnish the necessary men to fill the quota required of Rhode Islend by the President. A half million dollars was appropriated for enlisting and equipping men and mustering them into the service. Most of this money was obtained by the sale to several state banks of state bonds amounting to $\$ 350,000$ and of $\$ 100,000$ to Governor Sprague and his brother. It was also voted at this time to pay $\$ 12$ per month to each enlistee in addition to what he recelved from the federal government. 2

IThe_Narragansett WeekII (Westerly, R. I-), April 18, 186 ] 2 Ibid., April 25, 1861. 
The Westerly Rifles were the local untt of the Rhode Island state militia and had been organized since August, 1855.3 Since that time they had been an integral part of the state militia. On Tuesday, April 16, 1861, the organization convened for the purpose of accepting volunteers from the company and any others who wished to respond to the Governor's call for men to flll the state's quota. Before the meeting adjourned, a message was received from the Governor requiring the entire company to appear in Providence on Thursday, armed and equipped for war. 4

On the appointed day, April 18, the Festerly Rifles made all the necessary preparations in order to leave for the state capital. The people of Westerly, however, did not allow their men to depart without giving them their warmest wishes. A crowd of several hundred people gathered at the station to Iisten to speeches and engage in loud cheers for the soldiers. At the conclusion of the program the men embarked by train for Providence. Jpon reaching their destination the group met with disappointment. As a result of a mix-up in orders the company was directed to return to Westerly and await further instructions. After having received such a fine send-off, the Rifles must have been quite chagrined and embarrassed when they returned home that night. This feeling was short-

${ }^{3}$ Charter and Records of the Westerly Rifles (located in the Westerly Public Library), p.I.

4The Nerragansett Neekly, April 18, 1861. 
lived, however, for their commanding officer, Captain Card, received a communique from Governor sprague, relayed from Stonington, ordering him to entrain with his men for Providence early the next morning. Despite their temporary setback, the men of Westerly were finally off to the war. ${ }^{5}$ Of the 105 men who left for duty on that Apr1l morning most of them were probably either quite young or in the lower income bracket as only elght of them owned taxable real or personal property in the town. Six of these 8 were either commissioned or non-commissioned officers and only 2 of the remaining 99 men were tax payers. 6

Upon arriving in Providence, the Westerly Rifles were divided Into two details. The first was made up of Captain Henry Card, First Lieutenant William A. Chapman, Second Ileutenant James Babcock, Ensign J. Clark Barber, elght noncommissioned officers, two musicians, and forty-six privates. The second detall consisted of forty-five privates. The first detail left Providence for New York on Apr1l 20 with Governor Sprague and about half of the First Regiment, Rhode Island Volunteers. They salled on the steamer Empire State. The second detail, evidently left in the command of an officer from some other company, left with the rest of the regiment on

5 The Narragansett Weekly, Apr11 25, 1861.

6Tax Book (Westerly, R. I.), 1862. 
the following Wednesday. The Rifles from Westerly made up Company I in the First Regiment, Rhode Island Volunteers. 7

The regiment left New York on Sunday, April 21, and landed at Annapolis on Wednesday, April 24. The men were given quarters at the Naval Academy for that night and left the next morning for the Baltimore and Washington railroad line. In a letter home a Westerly soldier intimated that the regiment expected to meet with some kind of resistance as soon as it left Annapolis for Washington. Maryland at this time was still uncertain as to whether or not it would secede from the Union. Many acts of violence were perpetrated here by Southern sympathizers in the early stages of the war. Governor Sprague, who was leading the regiment, may have possibly averted trouble by telling the mayor of Annapolis that if a single man of his regiment was hurt he would return and destroy the city. No trouble materlalized and the men reached the railroad early Friday morning. They had marched twenty miles Thursday and six on Friday before reaching the tracks.

Evidently the First Regiment, which was the first in the nation to volunteer, was well recelved upon its arrival in Washington. In the same letter mentioned above, the author states: "Our regiment is praised more than any one here, ...

The Narragansett Weekly, April 25, 1861. 
and having the Governor with us, we are well treated wherever we go. 18

The second detail of the Westerly Rifles arrived in Washington some t1me previous to May 9. They were quartered at the Patent Office with the rest of the regiment from the country's smallest state. 9

Thinking that the war would be over in a very short time, the men who answered President Lincoln's first call for volunteers were mustered into the army for only three months and were not well instructed in the arts of warfare. Much pressure was brought to bear upon the chief executive to begin some action at once so as to give the people of the North a victory to heighten their spirits. Realizing that the volunteers' enlistments would soon be up, the President ylelded to pressure and gave the instructions which placed these inexperienced men in the first battle at Bull Run. The result was a severe defeat inflicted upon the North on July $21,1861$.

Because their three month enlistments were up the Rhode Island regiment returned home one week later on July 28. The arrival of the local men was expected and they were met by a large number of cltizens at the depot. Sorrow prevalled for a short time when 1t was announced that three men had been killed and two wounded, but the festiveness of the occasion could not be denled and the men were escorted joyously through

8 The Narragansett Teekly, May $2,1861$.

${ }^{9}$ Ib1d., May 9, 1861. 
the streets to the Armory. Here they were set upon by their frlends who plied them with questions and cheers. The enthusiasm reached such a pitch that at one point Captain Card was escorted to his carriage on the shoulders of several men. The celebration, however, was marked by tragedy. During the reception a salute had been planned by firing an old cannon, but the gun prematurely discharged, killing a young man named John H. Clarke. The townspeople were so incensed at this tragic turn of events that a group of them lifted up the cannon and threw it into the nearby Pawcatuck River. 10

\section{Captain Card}

Henry Clinton Card was born in South Kingstown on September 13, 1820. He received his formal education in the town of his birth and at the age of fourteen left school when he obtained employment in a woolen mill. When he was sixteen he moved to Westerly where he worked for much of his early life in the mill of Babcock and Moss. For a number of years he was in charge of the carding and spinning rooms in the mill.

On November 12, 1842, Card, who was then twenty-two, married Lois Phillips of North Stonington, Connecticut. This marriage ended elght years later when his wife died. Three years after her death, Card again married, this time to Marie Reynolds of Richmond, Rhode Island, who survived him. There were no children born to the first marriage, but his second wife bore him four girls and a boy. 


\section{$-14-$}

As a young man the future captain was unusually interested in military affairs and was connected in one capacity or another with the state militia from 1841 to 1877. In 1842 he served as a sergeant in the Dorr war. 11

Card was the leader in organlzing the Westerly Rifles, 12 and he was commanding the company with rank of colonel when the Civil War broke out. 13 When the Rifles were mustered Into the Onited States Army, their commanding officer was given the rank of captain. Opon the expiration of the ninety day enlistment, the Captain returned home with his men. ${ }^{14}$

In the spring of 1862 volunteering was at a low ebb, but a group of the Westerly Rifles enlisted with Captain Card and went to Washington in the latter part of May with the Ninth Regiment of Rhode Island Volunteers. The group made up Compant B in this regiment. Shortly after their arrival their leader was forced to return to Westerly to obtain fifteen or twenty more recruits to fill up the company. After acquiring the necessary number he returned to Washington laden with gifts for his men. 15 Because they had enlisted for only ninety days Company B returned home with the rest of the regiment in the last week in August after seeing only minor action. 16 After this

II The Westerly Sun (Westerly, R. I.), September 28, 1902.

12 Charter and Records of the Westerly Rifles, p.I.

13 Roster-Westerly Rifles (located in Westerly Public Library), p.3.

14The Narragansett Weekly, August 1, 1861.

15Ib1d., June 12, 1862

${ }^{16}$ Ib1d., September 4, 1862. 
enlistment the Rifles did not serve again as a complete unit in the army: The company became a part of a state militia group known as the Twelfth Regiment, Rhode Island Volunteers, and Card was elevated to the rank of major in this organization. 17

With the culmination of his service in the army, the commander of the Rifles became superintendent of the Babcock and Moss mill where he had been employed prior to the war. He remained in this position until the death of one of the owners of the firm caused changes in policy to develop. 18 Leaving this employment and his command of the Westerly Rifles in 1874, he moved outside the state and spent several years in farming.19. Eventually tiring of farm life, he returned to his home in Westerly. After his return he received employment as a policeman, truant officer, and armorer in charge of the state armory. After a brief 1llness he died at his home on September 25, 1902, at the age of eighty-two. 20

Armory $\mathrm{Hall}$

At a meeting of the Westerly Rifles on September 23, 1859, it was roted that a certain J. Swan be a committee of one to draft plans for an armory and to submit an estimate of the probable cost. During the same meeting it was voted that

17 The Narragansett Weekly, July 2, 1863.

18.The Westerly Sun, September 28, 1902.

19Roster-Westerly Rifies, p.3.

20The Westerly Sun, September 28, 1902. 
another member named James Babcock be a committee of one to Investigate and report on likely. locations for the proposed building.2l After several reports and much discussion a lot on Main Street was purchased from Iinden Taylor in February, 1860. In January, 1860, the General Assembly of Rhode Island appropriated $\$ 2,000$ for the purpose of helping to defray the construction costs of the armory. When Armory Hall was finally completed in 1861, the Rifles found themselves in an embarrassing position because they had overextended themselves and could not meet payment on the last bills which came due. The bills outstanding amounted to $\$ 1,775$. In 1ts January, 1862, session, the General Assembly appropriated the required amount and the bill was paid, but the state was given a mortgage on the lot and bullding amounting to $\$ 3,775.22$

When completed, Armory Hall was an impressive structure three storles high which through the years became the center of the town's military, social, and political activity. On the first floor a ten foot wide hallway led to the auditorium and stage where the town meetings and various forms of theatrical entertainment took place. A ticket office was located at the entrance to the auditorium or audience room as it was called. Also located on the first floor was a supper room measuring fifteen by thirty feet and an officers' room whose measurements were nine by fifteen feet. The second floor was

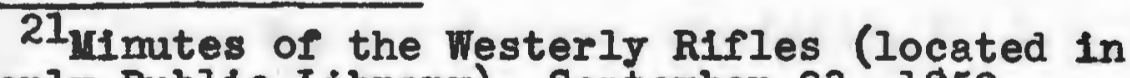
Westerly Public Library), September 23, 1859.

22 Ib1d., March 18, 1862. 
taken up with two company rooms where the militia companies could keep their equipment and hold their meetings. The thirty by forty foot squad drill room and a small store room were located on the third floor. 23

All town meetings during the Civil War and for many years after were held in Armory Hall. The town of Westerly paid the Westerly Rifles Company the sum of fifteen dollars whenever it used the building. 24

Throughout the war it was quite evident from the number of permits issued by the Town Council to dramat1c and musical companies that the people of the town were not lacking in entertainment. These performances were invariably held in Armory Hall. There were instances, however, where shows were put on without being properly licensed. In January, 1865, it was roted by the Town Council that licenses for shows or exhibitions could be granted only by that body. At this same meeting Jonathan B. Crandall and Benjamin York were appointed police constables especially for the purpose of keeping order at the Armory during such performances.25 Evidently a little "hell ralsing" had been taking place.

It was in this bullding that many of the stores and plants of the community gave parties and dances for their employees. On saturday evening, March 20, 1864, "a Blowout Ball was held

23 The Narragansett Week1y, February 27, 1879.

24Town Meeting Records (Westerly, R. I.), No. 8, pp.82-121. 25 Counc1l Records (Westerly, R. I.), No. 7, pp.154-90. 
at the Armory Hall, . - by the employees of O. M. St1llman and Company, who in that way expressed their pleasure that the season of lamplight work was over.n26

Naturally, the Rifles used their building for all of their social gatherings. It was a practice of the company to hold dances and falrs in order to ralse funds for their organization. Some of these were quite successful. In fact, a falr that was held on March 20, 1865, cleared $\$ 550.27$

Soon after its construction, the hall had risen to a point of near indispensability to the cltizens of Westerly. It was the focal point of a great deal of the work and relaxation of the people.

26 Phe Narragansett Weekly, March 24, 1864 . 27Ib1d., March 23, 1865. 


\section{CEAPTER III}

\section{THE DRAFT}

Recruiting for Volunteers

In his first proclamation of April 15, 1861, asking for 75,000 volunteers, President Lincoln gave the seceded states twenty days in which to disband their troops and have them return peaceably to their homes. ${ }^{1}$ on May 3, recognizing that his orders to the South were going to be ignored, the President issued a new proclamation. In this proclamation he asked for 42,034 volunteers to serve in the infantry and cavalry for a period of three years, 18,000 men to serve not less than one nor more than three years in the navy, and an increase in the regular army of 22,714 officers and enlisted men. 2

It should be noted that at this time the federal government had no legal means at its disposal for the actual draftIng of men into the armed forces. Instead, the government had to rely on the militia from the various states and the recruiting work of army officers throughout the North.

In attempting to fill the new quota established by the President's May 3 proclamation, the Onited States Army sent Captain C. Duckworth and Captain C. H. Chapman to Westerly to enroll volunteers. The two officers established themselves

$1_{\text {The Narragansett Weekly, August 1, } 1861 .}$ Ib1d., May 9, 1861. 
at the Armory on Main Street, "but owing to a recent alteration in the pay of volunteers from this state, the roll fills up slowly."3 The men of Rhode Island evidently did not feel too friendly toward their home state because of the decrease in the amount of money given to rolunteers. Already mentioned was an act passed on April 17, 1861, by the Rhode Island legislature. According to this act each volunteer was to receive the sum of twelve dollars per month while he was in service. The legislature of Rhode Island met in special session from August 8 to August 10, and the question of money to be given volunteers was discussed quite fully. It was finally decided that the sum of fifteen dollars was to be given each recruit when he was mustered into the army. 4 This meant that no longer would the Rhode Island volunteers recelve twelve dollars per month from the state. Meanwhile, across the Pawcatuck River in the Town of Stonington, Thomas D. Sheffield was attempting to raise a company of volunteers under the authority of Governor Buckingham of Connecticut. Sheffield, incidentally was a member of the recently returned Westerly Rifles. Several other members of the Rifles also crossed the river to join the newly formed Stonington Company. In Connecticut, besides

3The Narragansett Week1y, August 29, 1861. 4 Ibid., August 15, 1861. 
the thirteen dollars a month federal pay, the volunteers with families received an additional ten dollars per month and all volunteers recelved thirty dollars a year from the state. 5 The Town of Stonington also gave each volunteer ten dollars when he went into the service. 6 Evidently the higher pay given by Connecticut to its volunteers was the chief Inducement to the Rhode Island men.

There were three recruiting offices in the Town of Stonington: one in Mystic, where five men volunteered; one in stonington, where six men volunteered; and one in Pawcatuck, where seventy men were enrolled.7 of the seventy men enrolled in Pawcatuck, eight were former members of Company I, First Regiment, Rhode Island Volunteers. 8

The Connecticut company was quartered for a short time in Mystic until a full company had been raised. The full company was then sent to Camp Buckinghem near Hartford for training. From this time forward the company became part of Company $G$ of the Eighth Connecticut Regiment. 9 The company remained at this camp for approximately one month and

5The Narragansett Weekly, August 29, 1861.

6Ibid., October 3, 1861 .

7 Ibid.

8Ib1d., September 5, 1861.

9 Ibid., October 10, 1861. 
then was shipped to Camp Burnside near Annapolis. In November, 1861, the people on the Connecticut side of the Pawcatuck sent a box containing such things as stockings, blankets, sheets, and pillows to Company G. The gift was greatly appreciated by the men of the company because a letter was received almost immediately by the Volunteer Aid Committee from one of the grateful recipients. 10

Company G served with honor until the end of the war. Some of the battles engaged in were the selge of Fort Macon in April, 1862; the battle of Antietam in September, 1862, in which the Eighth Regiment received its severest losses; and the battle of Fredericksburg in December, 1862.

In December, 1863, many of the members of Company G re-enlisted and in January, 1864, returned to their homes on furlough. Their furloughs ended, the men returned to the Virginia battlefront and took part in battles at Walthall Junction, Fort Derling, Petersburg, and Fort Harrison. These battles took place from April to September of 1864. With the close of the war the Eighth was sent to Lynchburg, Virginie, where it remained for several months on police duty. The entire regiment was mustered out in December, 1865.11

10The Narragansett Weekly, December 26, 1861.

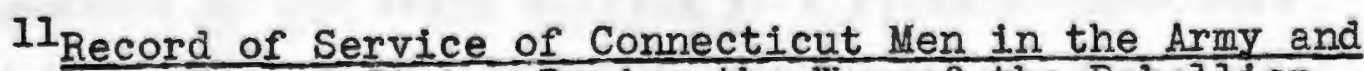
Navy of the Onited States During the War of the Rebelilon (Fartford: Case, Lockwood \& Brainerd Co., 1889), pp. 258-327. 
While the Connecticut regiment was being put into service in 1861, volunteering as a whole throughout the country was not progressing as rapidly as was desired. Consequently, In December, 1861, General McClellan began to reorganize the recruiting service. An efficient system might have resulted if Secretary of War Stanton had not interfered. On April 3, 1862, in a fit of overconfidence Stanton ordered the recruiting service to discontinue operations and ordered all officers back to the army. For various reasons the recruitIng system was restored on June 6, 1862, but it was too late to repair immediately the damage done by the discontinuance of recruiting. Since April the enlistments into the army had decreased to practically nothing, and officials were afraid that a call for volunteers might cause a national panic considering the recent reverses inflicted upon the Army of the Potomac. Therefore, a plan was developed whereby the various state governors would petition the President for a call for troops to bring immediate victory. The first call was for 300,000 men for nine months duty and 300,00 men for three years duty.

On August 9, 1862, the Adjutant General's office in Washington 1ssued an order relative to the recent call for nine month and three year men. This provided for the drafting of members of the state militia if a state's quota were not filled by volunteers. Each state was also instructed 
to make a list of all able-bodied male eltizens between the ages of eighteen and forty-five. 12

In order to keep the state militia at full strength In face of this threat, Governor Sprague made preparations for a possible state draft to fill the ranks of the militia. A. B. Chadsey was appointed Commissioner of Washington County for superintending this draft and on September 1, 1862, enrolled all men avaliable for a draft. A complete list of all such men was published in The Narragansett Neekly of September 4, 1862. Because of ensuing developments, an actual draft for this purpose was not necessary. It should again be emphasized, however, that at this time the federal government could not draft men into the services except through the state governments. 13

The nelghboring state of Connecticut was also having its difficulties with the conscription of men into the state militia. In January, 1862, the men of nearby Pawcatuck became quite apprehensive when they heard of this proposal. They misunderstood the purpose of such a draft and presumed that they would be sent off to war Immediately. Because of this misinterpretation, many Connecticut men tried to claim all sorts of disqualifying allments.

\section{The Narragansett Weekly, August 14, 1862. \\ 13Ibid., September 11, 1862.}


The principal defect in those already reported, is a stiffness in the joints. This difficulty is quite common, epidemic almost, and is becoming quite popular. We have no doubt that every man in Hartford will have a lame knee before the lst of March, even if he has to borrow one of a nelghbor. The list shows a very general lameness in arms, fingers, hands, or legs. Some men have been excused because, having ges, they see not; and others having ears, hear not. One way and another, the bulk of the people are exempt. Every men who ever had any disease, happens just now to find it budding and blossoming with perennial vigor, cherishes it as a blessing, and refuses to let a physician into his house. And these are our country's brave defenders. 14

The quota for Westerly under the August 9 call for volunteers was 43 three-year men. After some difficulty the local requirements were finally met on August $14,1862.15$ The town's quota of nine month volunteers was filled by the middle of October. 16

The early part of 1863 brought realization that the Northern army was decreasing in size at an alarming rate. Excessive casualties, desertions, ending of short-term enlistments, and a lethargy on the part of Americans in volunteering were the major causes of this problem.

14The Narragansett Weekly, February 6, 1863, quoting The Hartford Courant, n.d.

15 Ib1d., August 21, 1862.

${ }^{16}$ Ibid., October 16, 1862 . 
The Draft Act of March, 1863

On March 3, 1863, Congress passed an act calling for the drafting of men into the military service. This act made all able-bodled citizens, and all allens who had declared their intention of becoming citizens, between the ages of twenty and thirty-five liable for the draft. Onmarried men between thirty-five and forty-five were also to be taken.

Most states wondered how the draft would affect them, but, it was said that in apportioning the draft, credit was to be given to each state for the number of troops already furnished, but three year men were to be taken as the basis. Thus three regiments of two year men were considered as equivalent to only two regiments, and four regiments of nine months to one regiment of three year men.17

The names of all eligible men were written on cards and put in revolving cages at their separate district draft headquarters. The drawings were supposed to continue until the necessary number of names had been chosen. The actual drawings did not take place in each state at the same time, but instead were begun when each state was ready. The first drawings in the nation were started on July 7, 1863, in the state of Rhode Island.

It was always possible for a drafted man to use a substitute during the war. The Conscription Act made it legal for a draftee to hire someone to go in his place. Ontil an act of February 24, 1864, it was also possible for a man to pay the government $\$ 300$ for commutation of service. From 
this point on, substitution was the only legal way for a man to avold the draft, but even then a person was only exempt until the next draft. With the elimination of this avenue of escape from the draft, the price of substitutes went beyond the $\$ 300$ to which the commutation clause had held them.

Under the call of July 7,1863 , the number required of the Second District of Rhode Island, of which Westerly was a part, was 900 men. The number of men actually obtained by this draft was 535 of whom 340 were substitutes. This was only 59 per cent of the requirement. A total of 835 men were declared ineligible for reasons ranging from physical disability, of which there were 383 down to the only brother of fatherless and motherless children under twelve years of age. 18

It was not until the latter part of February, 1864, after increased recruiting, that the Governor issued a statement reassuring the people of Rhode Island that the state's quota had finally been filled. 19

Desiring to avert future drafts, the Rhode Island General Assembly in February, 1864, passed an act empowering the Governor to pay the sum of $\$ 300$ to all volunteers.20 This payment of $\$ 300$ to volunteers was quite different from the sum of fifteen dollers offered in 1861.

18The Narragansett Weekly, September 24, 1863.

19 Ibid., February 25, 1864.

20Ibid., February 4, 1864 . 


\section{$-28$ \\ Succeeding Drafts}

An act passed by Congress on July 4, 1864, authorized the President, at his discretion, to call any number of volunteers that he deemed necessary. If, after fifty days, the quota of any district was not filled, the President was authorized to order a draft in that section in order to fill the quota. On July 18, 1864, President Lincoln called for 500,000 volunteers. He proclaimed that a draft would be ordered on September 5 for every district that had not filled its quota by that day.21

The quota for Rhode Island under the call for 500,000 men was 3,917. The State excess on previous calls was about 2,000 , not including the men who had enlisted in the navy. The Providence press estimated the number of such at 1,600 . If the Government gave credit for these, there would be no draft in Rhode Island in September. Efforts were being made to obtain this credit. 22

In early September, it was announced that Rhode Island had filled her quota and was "out of the draft." 23

On September 26, in preparation for any future drafts, Samuel H. Cross wass appointed by the Town Council to enroll all persons in westerly liable for military duty. This was in accordance with an act passed at the January session of the General Assembly. 24

On December 19, 1864, a new call for 300,000 troops was ordered by Fresident Lincoln. This call was necessary in order

21

The Narragansett Weekly, February 25, 1864. 22

Ibide August 4, 1864.

23

Ibide September 8, 1864.

Council Records, No. 7, p. 179. 
to make up the deficiencies caused by credits given to states on the July, 1864 call of the President. ${ }^{25}$

In January, 1865, the Governor of Rhode Island announced that the quota of his state under the December call had been filled by enlistments. It seemed that once more Westerly and Rhode Island had escaped the draft.26 However, the ProvostMarshal-General evidently made a mistake in apportioning credits for volunteers to be deducted from the Rhode Island draft quota. Rhode Island was notified that its requirements were not filled for the last call. Immediately there was a renewed attempt by the state to procure more volunteers in order to avert a draft in Rhode Island.

Meanwhile, some members of the Rhode Island General Assembly went to see President Lincoln to ask for an extension of time because of the mistake made by the ProvostMarshal-General. The President told them he would "favor their requests as far as possible, but to go home and push the work of recruiting. ${ }^{27}$ The President's encouraging words in their minds, the General Assembly again authorized the Governor to pay $\$ 300$ to all volunteers. Golng one step further, they voted to give erery volunteer who was able to bring in a recruit other than himself the extra sum of $\$ 150$. This gave those liable to the draft a ndouble 1nducement to hunt up recruits. " 28

25 The Narragansett WeekIy, December 22, 1864. 26 Ibid., January 26, 1865.

27 Ib1d., February 9, 1865

${ }^{28}$ Ibid., February 16, 1865 
Shortly after the surrender of General Lee at Appomattox, and before a new draft was ordered in Rhode Island, the War Department issued a bulletin to the effect that all drafting and recruiting were to be stopped. This was called a "Cheering Bulletin" by the Narragansett Weekly. 29 
BOUNTIES TO SOLDIERS AND AID TO THEIR FAMILIES

\section{Early Bounties}

In the early stages of the war when soldiers wereobtained through the process of volunteering, It was the practice of the state and local governments to increase the number of recruits by offering a sum of money to all volunteers. This money was referred to as a bounty.

In the drafts of the latter part of the war the federal government deducted the number of volunteers from each state's quota. Most states and congressional districts thought that their prestige would be lowered if a draft were ordered in their area. Naturally, these areas did all they could to avert such an occurrence by offering liberal bounties to all volunteers so their quotas would be filled to prevent the necessity of a draft.

During the war unscrupulous men often enlisted in one state or district, recelved their bounty, deserted, and then reenlisted in another state or district. In this manner, if they were not caught, they were able to amass quite a fortune. Men who practiced this illegal act were called "bounty jumpers." It was because of these men that so many desertions were recorded in the reports of the Adjutant Generals during the Civil War.

Although there is not much information available on the subject of bounty jumpers as far as Westerly is concerned, a request was recelved from the Governor in August, 1862, to arrest and forward all officers and privates absent from their 
regiments without leave. The Town Council voted to notify any such person to report immedietely to the Adjutant General of Rhode Island, or exhibit to the Counc1l evidence of his discharge from the service. At a Town Council meeting on September 8, 1862, Benjamin York was euthorized to arrest all deserters and convey them to the Adjutant General. ${ }^{1}$ In October, 1862, the Town Clerk was authorized at a meeting of the Town Council to obtain the names of all persons in Westerly belonging to any regiment then in the service of the Onited States. He was also to get information on discharged men and the names of those on furloughs. When such information was gathered It was sent to the Adjutant General for careful scrutiny. 2

In October, 1863, Benjamin York arrested a man named George Wright, alias Jasper Wright, as a deserter. He was taken before the Board of Enrollment for questioning and then remanded with six other deserters to the military prison camp on Governor's Island. 3 Despite the lack of sufficient evidence, Nesterly probably had as much trouble with bounty jumpers as any other town.

On June 3, 1862, after the governors had petitioned the President for a call for 300,000 three-year volunteers, it was voted at a Westerly Town Meeting to pay the sum of $\$ 30$ to

lcouncil Records, No. 7, p.149.

2 Ibid, p. 150.

3 The Narragansett Weekly, October 29, 1863. 
all men who volunteered for three years or the duration. (At the above town meeting the bounty of a man named Le Clare was pald to his father. Evidently the bounty due a man under twenty-one years of age was paid to his parents.) 4 The people of Westerly did not realize how ridiculous this amount was soon to appear.

\section{Increase In Bounties}

A special town meeting was called in Westerly on August 4, 1862, for the purpose of increasing the bounty for volunteers from the town. The Westerly quote of 43 in the last call for 300,000 had to be filled to stave off a draft of the militia. At the August 4 meeting the local citizens voted to enlarge their bounty offer to $\$ 200$. This was to be pald as follows: $\$ 25$ when the volunteer passed his physical examination, \$75 when mustered into the service, the remainder to be paid in $\$ 25$ monthly installments. 5 Although no mention was made concerning the reason for this involved method of payment, it seems likely that this arrangement was devised to thwart bounty Jumpers.

Despite the seeming generosity of this latest bounty the quota for Westerly remained unfilled. The reason for this fallure was the even more generous offers of the neighboring towns of North and South Kingstown. Several of Westerly's

4Town Meeting Records, No. 8, pp. 94-95

5The Narragansett Weekly, August 7, 1862. 
young men went to North Kingstown and enlisted. The bounty there was $\$ 400$. Others went to South Kingstown where the bounty was $\$ 500$ but were turned away because the quota was full. Enlistment in other towns was an acceptable practice. Any town could accept volunteers from another town or state to fill its quota. 6 With this kind of competition confronting it Westerly had to increase its bounty again or face submission to a draft.

On August 14, 1862, a special town meeting was called to discuss this pressing problem. After some debate, it was decided to raise the bounty to $\$ 500$ and pay the entire sum when the enlistees were mustered into service. Because of this new offer, the 43 man quota was filled by bedtime. 7 In just a few days over two months Westerly went from a $\$ 30$ bounty of one of $\$ 500$.

By the end of August this competitive bidding by the individual towns in the state was causing these municipalities to go deeper in debt than state officials thought wise. This, however, was not the only problem which developed because of inflated bounties. When news of these large payments reached the troops in the fleld there was widespread dissatisfaction. "Why should these newcomers get so much more than we did?" they were saying. 8 To combat this new situation Governor

6The Narragansett Weekly, August 14, 1862.

7Ibid., August 21, 1862.

8Ib1d., August 28, 1862. 
Sprague called a special meeting of the General Assembly on August 25, 1862. On September 1 the legislative body passed a bill by which the state assumed the bounties paid by the towns and also provided for a uniform bounty. The maximum legal bounties allowed by this bill which the Governor signed were $\$ 300$ for three-year enlistees, \$150 for nine-month enlistees, \$150 for substitutes, and $\$ 100$ to those men who were drafted. 9

Although the Westerly quota for three-year men had been filled in August, there still remained the publicly unannounced quota of nine-month men on the August 9 call to fill. In order to stir up enthusiasm a "War Meeting" was called for September 22 at Armory Hall. Several speakers, Including Governor Sprague, addressed the gathering of interested citizens. At this meeting a "Patriotic Bounty Fund" was created to which many persons subscribed. The money from this fund was to be used for procuring volunteers sufficient to fill up the quota for nine-month men. The subscriptions received amounted to approximately $\$ 4,000$ and William P. Coy was appointed treasurer of the fund. It was reported at the meeting that thirty-five men had volced willingness to serve as nine-month volunteers. 10

At a meeting at Armory Hall on October 13, 1862, recruiting committee reported that the town's recently announced

9The Narragansett Weekly, September 4, 1862. ${ }^{10}$ Ib1d., September 25, 1862. 
quota of 93 nine-month volunteers had been filled. Only 20 of these volunteers were from Westerly. Oddly enough at this same meeting it was voted not to collect the balance of subscriptions toward the bounty fund but instead to return all the money that had been collected. ${ }^{11}$ Apparently the bill passed by the General Assembly on September 1 empowering the state to take over town bounties prohibited any further 1ssuances of bounties by the towns. This assumption is based upon action taken at a town meeting held on August 20, 1863. At this meeting a petition was drawn up asking the Governor to convene the General Assembly for the purpose of modifying or repealing "certain laws now existing which interfere with the voting of bounties to volunteers or drafted men by towns. ...n12

In January, 1863, the Governor announced the the Rhode Island quota for the August call was filled and no draft would be necessary. With the threat of a draft removed the General Assembly passed an act at its January session repealing the $\$ 300$ bounty paid by the state to rolunteers. ${ }^{13}$ At this same session it was announced that approximately $\$ 700,000$ had been paid out in 1862 by the state for soldier's bounties. 14

II The Narragansett Weekly, October 16, 1862.

12 Ibid., August 20, 1863.

${ }^{13}$ Ib1d., January 29, 1863.

14 Ibid., January 22, 1863. 
Since the Union army had suffered reverses and decreased in size in the spring of 1863, it was announced in June that some new six-month regiments would be started. In the same month the War Department requested troops from Rhode Island to help repel Lee's invasion of Maryland and Pennsylvania. To encourage men to volunteer the State of Rhode Island offered a new $\$ 300$ bounty for three-year enlistees and $\$ 100$ for six-months men. Several Westerly men enlisted at this time. 15

As has been previously mentioned, the Rhode Island quota under the July 7, 1863, call was not filled until late February, 1864. Alarmed at the fallure of Rhode Island men to volunteer and thus avert the direct draft made legal by the March, 1863, federal act, the General Assembly passed a new bonus bill in its January, 1864, session. This empowered the governor to give a bounty of $\$ 300$ to recruits "until enough men were raised to fill Rhode Island's quota." 16 within a month the quota was reached.

Still striving to swell the number of volunteers so that these would offset the quota of any future call, the state of Rhode Island increased its bounty to $\$ 400$ in July, 1864. It was also announced at this time that any citizen bringing in an acceptable recruit would receive from the federal government

\section{${ }^{15}$ The Narragansett Weekly, June 25, 1863. 16Ibid., February 4, 1844 .}


$\$ 15$ for a veteran and $\$ 10$ for a non-veteran. In addition the State of Rhode Island offered $\$ 50$ to any citizen who brought in a recruit. 17

The next bounty authorized in Rhode Island came in February, 1865, and amounted to $\$ 300$. This was necessary to help fill the re-ramped quota caused by the Adjutant General's mistake on credits given for the July, 1864, call.18 Since the fighting was over about two months later this proved to be the last of the Rhode Island bounties in the Civil War.

Relief Committee and Overseer of the Poor The citizens of Westerly were not negligent in their care for the families of soldiers away at the front. As was true of other towns in the North, Westerly took care of 1ts own.

At a well-attended town meeting on October 27, 1862, the freemen of Westerly voted to pay $\$ 4$ per week from the town treasury to the families or dependents of nine-month volunteers. This money was in addition to the bounty and federal pay that a serviceman received. 19 At a special town meeting held on July 17, 1863, the same sum was voted. At this meeting Amos Collins, John Pendleton, and Samuel H. Cross were appointed as a committee to oversee this aid and were given

\footnotetext{
17 The Narragansett Weekly, July 14, 1864. ${ }^{18}$ Ibid., February 9, 1865. ${ }^{19}$ Ibid., October $30,1862$.
} 
power to draw on the town treasury.20 In April, 1864, E. B. Pendleton replaced Amos Collins on this committee but the payments were kept at \$4. However, it was voted at this meeting that the recipients of this aid were only to be families of Westerly volunteers in Rhode Island regiments. This eliminated Westerly men serving in Connecticut regiments from receiving any aid. 21

From 1861 to 1866 the Relief Committee paid out a total of $\$ 5,258.13$. The highest amount paid out in any one year was in 1863, when the total exceeded $\$ 1,700$ (Appendix I). 22 This seems to indicate that the largest number of men from Westerly serving in the armed forces in any single year was in 1863. However, there are no actual enrollment records to further substantiate this assumption.

The duties of the Relief Committee were not officially connected in any way with those of the overseer of the poor. It was one of the duties of the latter official (George D. Cross was elected throughout the war) to give assistance to those citizens of the town who were without sufficient food and clothing and had no Immediate means of improving their situation. The care of the poor was an entirely local function and legal residence in the town had to be certified before any aid could be given.

20Town Council Spectal Proceedings (Westerly, R. I.), No. 1 , pp. 36-37.

21 22 Town Meeting Records, No. 8, p. 109. Counc1l Records, No. 7, passim. 
The Civil War had a definite effect on the amount of money expended by the overseer of the poor. From the years 1856 to 1860 , the sums spent by this official varied between $\$ 1,000$ and $\$ 1,500$ (Appendix II). When the war began in 1861, the overseer's expenditures dropped below $\$ 1,000$ for the first time in at least six years. Only once during the Civil War did this amount exceed $\$ 1,000$ and this was in 1864 when $\$ 1,015.06$ was paid out.23 This drop in payments can be explained in at least two possible ways or a combination of these two. First, the Civil War brought an increase in business to Westerly and jobs became more plentiful. This enabled men receiving assistance from the town to provide for themselves and their families. Second, men who had been recelving this aid volunteered and no longer needed it.

To support this theory an examination of the eccounts of the Relief Committee showed that it pald out its largest sums to families of soldiers in 1863 and 1865. A similar examination of the records of the overseer of the poor (Appendix II) showed that his lowest expenditures during the Civil War came in the same two years. This indicated that there was some correlation between the disbursements of the overseer and the number of men who left Westerly to fight for the North.

${ }^{23}$ Council Records, No. 7, passim. 


\section{CHAPTER V}

ECONOMIC EFFECT OF THE WAR

Rise in the Cost of Government

During any war there is a tendency for the prices of goods and services to spiral upward. As these prices increase, the costs of government, whether local or national, inflate with them. The Civil War had such an effect on Westerly.

For several years prior to the war the taxes on real and personal property had remained constant at fifteen cents for each $\$ 100$ of evaluated property. As the normal costs of government increased, and such expenses as aid to the families of soldiers were added, it was necessary to adjust the local tax rate in 1862. At the June town meeting in this year it was decided to double the tax rate by increasing it to thirty cents on each $\$ 100$ worth of property. I In the summer of 1862 , the town found it necessary to increase the bounty offered to volunteers from $\$ 30$ to $\$ 500$. This unexpected addition to the town's expenses led to a fump in the tax rate from thirty to fifty cents. 2 However, when the state announced 1ts assumption of all local bounties, the rate was lowered to that established at the June town meeting.

During the fiscal year from June, 1862, to June, 1863, prices and costs continued to mount. This again necessitated an increase in the rate to fifty cents at the June, 1863,

$I_{\text {The Narragansett Weekly, June 12, } 1862 .}$

2Ib1d., August 21, 1862. 
meeting. 3 In June, 1864, the taxes were raised again, this time to sixty cents on every $\$ 100.4$ In four years the local taxes increased four fold.

Another example of inflationary trends caused by the war was the increase in the compensation of the town tax collector (Appendix III) from 1861 to 1866. This was not an elective office; instead, the official obtained his position through a process quite similar in some respects to that practiced in the Roman Bmpire. Every June the office of tax collector was put up for bid and usually the low bidder was given the job. In 1861 the tax collector recelved the sum of $\$ 11$. The winning bid for this position increased every year until in 1864 the lowest bid was $\$ 73$ or an increase of 663 per cent in three years. In 1865 , there was a slight decrease to $\$ 70$, but in 1866 there was an abrupt drop to $\$ 21 .^{5}$ No explanation was given for the quick decrease in the amount but a possible one might have been an increase in competition caused by returning veterans.

The costs of running the war had put such a strain on the national treasury by the summer of 1861 that in september the government announced it was going to institute a national income tax for the first time in the history of the Onited States. This tax was to go into effect on January 1, 1862 , placing a levy of 13 per cent on all incomes over $\$ 800.6$

3 The Narragansett Weekly, June 4, 1863.

4 Ibid., June 9, 1864 .

5Town Meeting Records, No. 8, passim.

6 The Narragansett Weekly, September 5, 1861. 
A later act brought the tax to 5 per cent on incomes from $\$ 600$ to $\$ 5,000$ and 10 per cent on any amount over $\$ 5,000$. All citizens of Westerly in these income levels were subject to this tax.

The scarcity of records made it difficult for the writer to ascertain an over-all picture of the effect the war had on Westerly industries. It is known that some of the local plants had difficulty in completing contract work for the government because of loss of employees through enlistment. In one shop where "quite a bit of gun work" was done for the government, several of the best workers enlisted. 7 The Cottrell and Babcock company lost five apprentices, the engineer, and one blacksmith when the Westerly Rifles left in April, 1861.8 Again, little information is avallable on the value of war contracts given to Westerly factories by the government. Some of the town's woolen mills did receive government orders for making the cloth which was used in manufacturing uniforms. Cottrell and Babcock, now The Cottrell Company, made gun parts for the government arsenal at springfield, Massachusetts. 9 On the whole, however, a detalled description of war orders and their value can not be given because of the lack of proper data.

TIhe Narragansett Weekly, August 14, 1862 . 8 Ibid., April 25, 1861.

${ }^{9}$ Ralph Bolton Cooney, Westerly's Oldest Witness (Providence: Akerman Standard Press, 1950), p. 34 . 


\section{$-44-$}

The retall stores of Westerly rarely advertised the prices of their goods in the local newspaper, although most of them used this medium to publicize the various merchandise they had for sale. Occasionally some mention would be made in the news section of The Narragansett Weekly of local retail prices, indicating the Westerly consumer was often faced with increasing costs. In a two month period in 1862, coal went from $\$ 5.50$ to $\$ 7$ per ton. 10 In 1864 the rising prices of paper and labor caused The Narragansett Weekly to raise its subscription rates from $\$ 1.50$ to $\$ 2$ per year. The advertising rates were also increased from 40 to 50 cents per inch. ${ }^{11}$

\section{Rowse Babcock III}

The career of one Westerly businessman gives some useful insight into the local business conditions of this period. This man was Rowse Babcock III. In writing about Babcock, however, a clear picture can not be portrayed without mentioning his partner, Jesse L. Moss.

As closely as can be ascertained, Babcock and Moss became partners in business around 1838, with the purchase of the White Rock Company from Blodgett, Stafford, and Simmons. The former owners of this textile mill had been operating unsuccessfully and had suspended the planned enlargement of plant facilities and the building of a mill village. Babcock and Moss, after gaining ownership, successfully

\section{The Narragansett Weekly, October 16, 1862. \\ ${ }^{11}$ Ibid., September 15, 1864.}


undertook the completion of these projects. The construction of the mill and twelve double houses called for in the original plan created a mill village which, when it opened in 1849, was halled as "a model of 1 ts kind. "12

Babcock was elected Representative from Westerly to the State House of Representatives in June, 1863. He replaced Nathan F. D1xon who had resigned the same month. In April, 1864, he was re-elected to this position. ${ }^{13}$ While serving in this office, he was appointed a member of the Committee on the Judiclary as well as a member of a special committee in relation to banking. 14

In 1861 Babcock and Moss began construction of a new two story, brick bulla1ng flfty by one hundred feet in size on Cahal street. This was needed to take care of government orders just recelved. The flrst floor of the new bullaing was used as a Iinlshing room, and the second floor as a weaving shop. While this construction was in progress the rest of the m1ll was running full t1me. ${ }^{15}$ Again in 1863, Babcock and Moss completed 1mprovements in their mill consisting of a new stone engine-house and a new water wheel. 16 obviously the partnershlp prospered from 1 ts business with the government.

12Cooney, Hesterly's Oldest W1tness, pp. 24-25.

$13_{\text {Town Meeting Records, No. } 8 .}$

14 The Narragansett Weekly, January 21, 1864.

I5 Ibid., October 10, 1861.

16 Ib1d., November 19, 1863. 


$$
-46-
$$

These two men did not confine their business interests to their partnership alone. In his younger days, Rowse Babcock had owned a share in the schooner Spartan which sank in 1828, after cargo and crew were saved. 17 Jesse Moss became president of the Westerly Savings Bank, incorporated in 1854. Rowse Babcock was the first president of the Westerly Gas Light Company or ganized in 1867.18 Babcock and Moss began construction of a new hotel, the Dixon House, in 1866. It was completed in 1868, and was claimed to be the largest and most costly hotel in Rhode Island at that time. ${ }^{19}$ In 1864 Rowse Babcock was elected one of the trustees of the River Bend Cemetery Company. 20

The White Rock Company received quite a substantial amount of business from the government during the war. In August, 1861, the company received a federal contract for the manufacture of 120,000 yards of flannel at twenty-five cents per yard. 21

In 1863 the spinners employed by the White Rock Company went on strike for higher wages. They were receiving $\$ 1.25$ per day and were asking to have this increased to $\$ 1.50$ per day.22 Again, in 1864 a strike by some of the employees of

17Denison, Westerly and Its Witnesses, p. 229.

${ }^{18}$ Ib1d., p. 235.

19 The Westerly Sun, Febr-uary 18, 1926.

20 The Narragansett Weekly, January 21, 1864.

$21_{\text {Ibld., August 22, } 1861 .}$

22 Ibid., December 3, 1863. 
Babcock and Moss caused the closing of the Stone Mill and a portion of the Stillmanville works.23 The outcome of these strikes received no publicity in The Narragansett Weekly. It is interesting to note that they preceded by some ten or fifteen years the wave of strikes which swept the country beginning in the 1870 's.

A comparison of the real and personal evaluations of Babcock and Moss and the entire town of Westerly (Appendix IV) gives an indication of the increase in the fortunes of these men between the years 1853 and 1866. From 1853 to 1866 Babcock's real and personal evaluation increased by 660 per cent, Moss's increased by 1,400 per cent, while the town's increased by 180 per cent. 24 These figures do not include the value of their jointly owned property. In 1861 the White Rock Company was evaluated at $\$ 110,000.25$ Even taking into account a possible increase in the percentage of the town's evaluation It remained quite apparent that Babcock and Moss made appreciable additions to their personal estates.

In 1863 Babcock received the second highest income in Westerly. In this year he made $\$ 47,945$ and paid $\$ 2,397.25$ in

23 The Narragansett Weekly, July 28, 1864.

24 Tax Book (Westerly, R. I.), 1853, 1859, and 1866.

25 The Narragansett Weekly, November 28, 1861. 
income tax. Jesse Moss earned the fifth highest salary in 1863, w1th $\$ 21,040$, and paid an income tax of $\$ 1,052.26$

In view of these facts it seems reasonable to assume that the other industries and businessmen in town must have been alded in some degree by the increase in business during the Civil War.

Babcock died on March 6, 1872, when he was sixty-nine years of age. It appeared that he had some definite plans for the future when death took him. "Some three months ago, he returned from a tour of Europe, and since his return had been occupled with plans to beautify the place which gave him birth, and with the prosperity of which he had been from first to last been identifled." His death was mourned by most of the local citizens and a poem was written in memory of h1m.27

26The Narragansett Weekly, February 9, 1865. The highest income of $\$ 63,686$ was earned by the estate of W. Stiliman and a tax of $\$ 3, .184 .30$ was paid. Edwin R. Brown was third with earnings of $\$ 41,857$ and a tax of $\$ 2,092.85$. H. N. Campbell was fourth with earnings of $\$ 33,744$ and a tax of $\$ 1,052$.

27 Abby Gardiner (ed.), "Westerly Vital Statistics" (n.p., n.d.; in Westerly Public Library), I, 42-43. 


\section{CHAPTER VI}

WATCH HILL

George Nash and the Watch Hill House

In the 1830's Captain Jonathan Nash, the lighthouse keeper, was the owner of sixty-one acres of lend at Watch Hill. At this time many Westerly residents came to the Hill by small boats or carriage to enjoy the seashore, and some of the Watch Hill home owners made extra money by serving meals to these people. Recognizing the potentlalities of the situation, Nash in the early $1840^{\prime}$ 's started the first hotel called the Watch Hill House. This business venture was only moderately successful at first, and in 1844 he sold the hotel and elght acres of surrounding land to his son, George Nash. In the following years George made several small additions to the building in order to accommodate more customers. This was the only hotel in Watch Hill for many years. ${ }^{1}$

In 1856 Hanry Dickens, a son-in-law of Jonathan Nash, and a man named Taylor opened the second hotel which they called Atlantic House. By 1858 both establishments were carrying on a steady summer business in catering to dally excursionists and house guests. 2

An examination of George Nash's real and personal evaluations and business transactions shows how the property values in Watch Hill skyrocketed during the Civil War. From

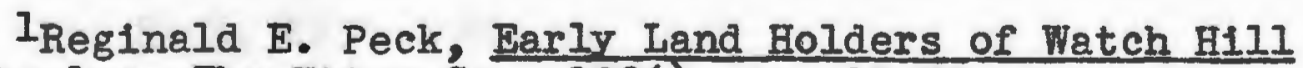
(Westerly: The Utter Co., 1936), pp. 19-20.

2 The Narragansett Weekly, July 1, 1858. 
1855 to 1865, George Nash's total evaluation rose from $\$ 13,500$ to $\$ 18,000$, increase of $\$ 4,500$ or 33 per cent. During this period the evaluation of his real estate never rose above $\$ 12,000 .^{3}$

In 1865 Nash accepted an offer by Sarah Burger of Hartford to buy his property. When he bought this land and hotel in 1844, Nash had paid his father $\$ 2,400.4$ The entire property was sold to Sarah Burger for $\$ 38,000$. The assessor of the tow of Westerly, which included Watch Hill, must have had his eyes opened by this sale because in 1865 the property was re-evaluated and taxed for $\$ 35,000$. This was an increase of 191 per cent over the former evaluation of $\$ 12,000.5$

Westerly People Visit Watch H1ll

In the 1850's the people of Westerly were taking full advantage of the relaxing atmosphere of Watch H1ll. The most popular route followed was the road, or path, leading through Lotteryville, now called Avondale, In July, 1858, a complaint appeared in The Narragansett Weekly concerning the number of gates which obstructed this road. Two had been removed but five still remained. Sons of farmers whose land was crossed by the road would spend most of the day at these gates waiting for carrlages to pass. When one approached, the occupants of the vehicle would ask the boys to open the gates and then pay them for this service. After the carriage passed, the gates

${ }^{3}$ Tax Book, $1855-1856$.

4peck, Early Landholders of Watch H111, pp. 19-20.

5Tax Book, 1865. 
were closed and the next customers were awaited. Some of the young men made as much as $\$ 75$ in a summer by this method. The article suggested that the town should do something about opening the highway and improving its condition. 6

Church groups and other organizations often hired boats and went down the Pawcatuck River to Little Narragansett Bay. On reaching the bay they traveled past its shores until they found a suitable place for a picnic. Beaching their boats, they spent the rest of the day playing games, eating and having a good time in general. These excursions usually started in May and ended in September. 7

On July 5, 1858, in celebration of the Fourth which fell on Sunday, an estimated crowd of from 600 to 800 visitors came to the Hill to enjoy thenselves by bathing and strolling on the beach. About 350 were served dinners at the two hote1s. 8

In August, 1861, The Narragansett Weekly published for the first time a list of vacationers staying at Watch Hill. Several people from New York were emong those Iisted. 9 The practice of printing this roll was continued in following summers. 10

6The Narragansett Weekly, July 8, 1858.

TIbid., passim, 1858-1856.

${ }^{8}$ Ibid., July 8, 1858.

9 Ib1d., August 22, 1861.

10 Ibid., passim, 1861-1865. 
Excursion Boats to Watch Hill

Probably the most pleasurable of all modes of transportation to Watch Hill was to be found on one of the Pawcatuck River steamboats. These boats ran regular schedules, except when the river was iced over, to Stonington, Mystic, New London, and up the Thames River to Norwich.

One of the first steamboats on the river was the 103 foot Water Lily built by the Sheffield boat yard in 1850. For two years this craft covered the route to Norwich, but in 1854 it was sold to a Providence firm. In 1858 the Water Lily returned to Westerly and resumed its trips to Norwich. 11 In the summer of the same year, the owners of the ship announced that stops would be made at Watch Hill on the trips to and from Norwich. To induce passengers to take the excursion trips to New London and Norwich a round trip ticket was sold for the price of a one-way trip. Trips to Watch Hill were not included in this sale.12

In addition to their scheduled trips, the steamboats were also available to groups for chartered trips. The favorite destination on these trips was Watch Hill.13 on June 26, 1858, the Westerly Band made an excursion to Watch H1Il on the Water Lily. The group left Westerly at 7:30 A.M. and upon arriving at the Hill spent the day enjoying themselves. For dinner the party went to George Nash's Watch

${ }^{1}$ Everett Barns, "Pawcatuck River Steamboats, "Westerly Historical Soclety-Records and Papers (Westerly: The Otter Co., 1932), p.9.

\section{The Narragansett Weekly, August 5, 1858 . \\ ${ }^{13}$ Ibid., passim, 1861-1865.}


H1ll House where "they partook of an excellent collation." The return trip was started at 11:00 P.M.14

In July, 1858, a large sail boat, the Mohegan commenced operations on the Pawcatuck. Throughout the summer this boat left Westerly at 8:00 A.M. for Watch Hill and made the return trip starting at 4:00 P.M. The captain, George S. Wilcox, made a specialty of accepting fishing parties and excursions. 15

A desire to "get away from it all" and spend a few pleasant days or weeks in enjoyment was quite prevalent. People appeared to have the need to leave the troubles of the world and crawl into a shell of pleasure where outside pressures and fears could not touch them. By 1863 vacationists were coming to Watch Hill in ever increasing numbers. However, there was no direct rail connection to their destination, and it was necessary to leave the train at Westerly if the passengers were arriving from Providence. Passengers going to Watch Hill from points in Connecticut and New York usually got off at Stonington. From Westerly and stonington the trip was usually completed by boat.

Planning to share in the proceeds of this increasing traffic a man named Loper from Stonington had a new steamboat called the Dashing Wave built in the spring of 1863. Loper planned to have the craft leave Westerly twice a day during the summer - once in the morning and again at night. 
We understand that the arrangement is for her to leave Stonington about 8 o'clock in the morning, on the arrival of the accommodation train from Groton, land passengers at Watch Hill, and come to Westerly in time to receive passengers from Providence at 9 o'clock, and take them, with anybody else who wants to go, to Watch Hill. She will then make hourly trips between Stonington and Watch Hill, until some time towards evening, when she will again run up to Westerly, and return to stonington to spend the night. This arrangement will prove a great accommodation; and if the fare is placed so low as ten cents, which is the price we have heard named, the boat will be extensively patronized.16

The vessel did not arrive in Stonington until the end of July and on its first trip up the Pawcatuck to Westerly it was found that the channel was too shallow to accomodate her draft. 17 Consequently, during the summer and fall of 1863, the Dashing Wave traveled exclusively between Stonington and Watch Hill. In May, 1864, the boat was sent to Philadelphia to be lengthened and have her draft of water reduced so it could navigate on the Pawcatuck.18 After repairs were completed, 2 new schedule was announced in July.

The Steamer Dashing Wave is to run daily between Westerly and Watch Hill commencing July 13, She will leave Westerly at 9:30 A.M.; and returning, w1ll leave Watch Hill at 3 P.M. She is also to make two trips a. day between Stonington and Watch Hill, leaving Stonington at $8 \mathrm{~A} . \mathrm{M}$. on the arrival of the accommodation train from New London, and at 2 P.M. Returning, she will leave Watch Hill at 11:30 A.M. and at 5 P.M. I9

16 The Narragansett Weekly, June 11, 1863.

17 Ibid., August 6, 1863.

${ }^{18}$ Ibid., May 26, 1864 .

19 Ibid., July 14, 1864. 
The continued growth of the tourist trade brought a new steamboat named Fanny into the picture on July 17, 1865. This boat ran between Stonington and Watch Hill to "accommodate excursionists from Norwich, New London, Mystic and Stonington. n20 In July, 1869, Rowse Babcock ana Jesse Moss, enterprising businessmen that they were, began operation of a steamer called the Belle between Westerly and Watch H1ll. 21

New Hotels and Cottages Built

When the Civil War was over several new hotels were built in Watch Hill by enterprising men who believed in the future of the resort. In 1866 A. S. Plympton of Hartford, Connecticut built the Plympton House which he ran for a few years before selling it. 22

In 1866 Babcock and Moss began the construction of a new hotel on Broad Street in Westerly. Completed in June, 1868, 1t was called the Dixon House. The Dixon House was a yearround hotel, but it was built primarily to take care of summer guests who were interested in the seashore. To transport their guests to Watch Hill Babcock and Moss had the steamboat Belle built. 23 The boat ran for thirteen continuous seasons, but

20 The Narragansett Weekly, July 20, 1865. 2lBarns, "Pawcatuck River steamboats," pp. 16-17. 22 peck, Farly Land Holders of Watch F111, p.22. ${ }^{23}$ Barns, "Pawcatuck River Steamboats," pp. 16-17. 
the Dixon House lost much of its summer business when more hotels in Watch Fill opened up. $24^{\circ}$

In 1869 the Larkin House was completed at Watch B1Il and opened to the public. Additions were made to it until for a time it was the largest hotel at the Hill. By this time George Nash must have been sorry he sold the Watch Hill House, because he proceeded to build a new hotel called the ocean House. This hotel is still flourishing, although several additions and renovations have been made. Other smaller inns built at this time were the Narragansett House, the Bay View House, and the Dickens House. 25 The Narragansett House is still operating, although it has assumed the name Narragansett Inn.

James I. Howard was the first person to build a sumer cottage at Watch Hill, which was completed in 1870. Some Watch Hill residents sold their homes to people who turned them into sumer dwellings. In succeeding years more and bigger summer homes were built. 26

In 1867 a road from Lotteryville to Watch Hill was completed by the town of Westerly at an approximate cost of $\$ 8,000.27$ This construction gives further emphasis to the increase in the amount of traffic going to Watch H1Il and to the firm establishment of the resort business there.

\footnotetext{
24 The Westerly Sun, February 18, 1926.

25Peck, Early Land Holders of Watch H111, p.22. ${ }^{26}$ Ibid., p.23.

27Denlson, WesterIy and Its Witnesses, p. 212.
} 


\section{CHAPTER VII}

\section{CONCLUSION}

A summation of this paper at first glance might lead a reader to conclude that the men of Westerly and the North in general were not very patriotic during the Civil War. It seemed, except for the beginning of the war when many volunteered, that the government and the people of Rhode Island spent much of their time and efforts in evading the draft.

Compared to present day concepts of patriotism this conclusion might be justified. However, it must be remembered that this government, at the time, was less than one hundred yeers old. In the simpler society of the time the people were much more conscious of their rights, and when the government took any steps which they thought might jeopardize these rights, they were quick to protest.

The draft laws enacted during the Civil War were the first to be used in the United States. Many men felt that these laws usurped their rights as citizens and gave the government more power than had been delegated to it by the Constitution. In some sections of the United States, antagonism toward the draft laws occasionally burst forth in the form of riots. The state of Rhode Island fortunately experienced none of these.

It must also be remembered that all states considered it an insult and a disgrace to be subjected to a draft. Hence, the use of such devices as the pald substitutes and bounties. 
Since the states used every method possible to evade a draft, 1t was logieal and natural that individuals would make the same attempts.

The Civil War tended to have a moderating influence on the intolerant attitudes of the people. The Wide-Awakes, so popular in Westerly in 1860, had begun to decline by 1863 . The nativist feeling had lost much of its force because of the gallant action of so many non-citizens in the war. ${ }^{1}$ In 1863 a poem (Appendix V) appeared in The Narragansett Weekly which depicts the general attitude toward the Wide-Awakes by the middle of the war. ${ }^{2}$

The decrease in the expenditures of the overseer of the poor during the war period indicate that employment opportunities became more numerous. Also, the obvious enhancement of Babcock and Moss' fortunes further substantlate the belief that other business activity in Westerly increased appreciably during the Civil War. ${ }^{3}$

The Westerly granite industry developed extensively after the war as a result of the demand for Civil War memorials. The writer believes that the major lasting impression left on Westerly by the Civil War, apart from the sorrow of lost sons, brother or fathers and the growth of patriotism, was the development of Watch Hill as a nationally-known resort.

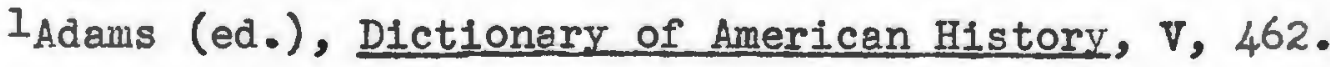
2 The Narragansett Weekly, April 30, 1863.

3 The Westerly Sun, passim, January 13-19, 1955.
} 
The increase in the number of steamboats and hotels, and the building of a road to the Hill combined with the growth of publicity given to Watch Hill in The Narragansett Weekly, provide concrete proof that Watch Hill got its start on the road to success during the Civil War. From Watch Hill the vacation area spread to Misquamicut and Weekapaug. Who can measure the importance of these resorts to Westerly through the years? 


\section{APPENDIX I}

A record of the Rellef Committee concerning the amounts of money given as aid to the families of volunteers from the town of Westerly during the Civil War. (Obtained from the Westerly Councll Records No. 7.)

YEAR

1861

1862

1863

1864

1864 (For 1862 and 1863)

1865

1866 (For 1865)

TOTAL
AMOUNT PAID OUT

$$
\begin{array}{r}
108.00 \\
635.93 \\
1,708.00 \\
913.00 \\
314.20 \\
1,555.00 \\
24.00 \\
\hline \$ 5.258 .13
\end{array}
$$




\section{APPENDIX II}

A record of the expenditures of the Overseer of the Poor of the town of Westerly from 1856 to 1865.

YEAR

1856

1857

1858

1859

1860

1861

1862

1863

1864

1865
AMOUNT PAID OUT

$\$ 1,000.99$

$1,244.93$

$1,509.01$

$1,322.12$

$1,021.44$

985.88

897.42

815.66

$1,015.06$

810.45 


\section{APPENDIX III}

A record of the pay of the Tax Collectors of the town of Westerly from 1861 to 1866.

DATE OF TOWN MEETING NAME OF COLLECTOR AMOUNT OF PAY

$\begin{array}{lll}\text { June 4, I86I } & \text { Asher Babcock } & \$ 11 \\ \text { June 3, } 1862 & \text { George Coy } & \$ 14 \\ \text { June 2, 1863 } & \text { Benjamin York } & \$ 50 \\ \text { June 7, 1864 } & \text { George G. Wells } & \$ 73 \\ \text { June 6, 1865 } & \text { George G. Wells } & \$ 70 \\ \text { June 5, 1866 } & \text { George G. Wells } & \$ 21\end{array}$


APPENDIX IV

A comparison of the total real and personal evaluations of the Town of Westerly, Rowse Babcock, and Jesse L. Moss for the years 1853, 1859, and 1866.

Year

Total Town Evaluation

Babcock

Mo 88

1853

$\$ 1,203,600$

$\$ 46,000$

$\$ 10,000$

1859

1,989,275

100,000

23,000

1866

$3,363,500$

350,000

250,000 


\section{APPENDIX V}

Some of the stanzas of a poom entitled "The Drafted WideAwake" which appeared in the Narregansett Weekly, April 30, 1863.

I was a glorious Wide-Awake,

All marching in a row; ,

And wore a shiny oll-cloth cape,

About two years ago.

Our torches flared with turpentine,

And filled the streots with smoke;

And we were sure, what'er might come,

Secession was a joke.

Refrain:

Oh, if I than had only dreamed

The things that now I know,

I ne'er had been a Wlde-Awake,

About two years ago.

I sald the South would never dare

To strike a single blow;

I thought that they were cowards then,

About two years ago.

And so I marched behind a rail,

Amed with a wedge and maul;

With Honest Abe upon a flag,

A bostman gaunt and tall.

Refrain: 
One brother's bones half buried lie ivear the Antietam's flow;

He was a merry happy lad, About two years iso.

And where the Chickahoritiny roves sluggish toward the sea, Was left another's wasted corpse-I am the last of tnree. Refrain:

Just now I saw rny torch and cape, ihich once made such a show; They are not now what once they seemed, About two years ago.

I thought I carried freedon's light, In that smoky, flaming banc; I've learned I bore Destruction's "torch"-That "wedge" had split the land. Refrain: 


\section{Articles}

Barns, Everett. "Pawcatuck River Steamboats," Westerly Historical Soclety--Records and Papers. Westerly: The Utter Company, 1932.

\section{Books}

Adams, James Truslow. Dictionary of American History. Vols. II \& V. New Tork: Charles Scribner's Sons, 1940.

Bragdon, Henry W. and McCutchen, Samuel P. History of a Free People. New York: The Macmilian Company, 1955.

Cooney, Ralph Bolton. Westerly's Oldest W1tness. Providence: The Akerman-Standard Press, 1950.

Denison, Fredric. Westerly and Its Witnesses. Providence: J. A. \& R. A. Reld, 1878 .

Field, Edward (ed.). State of Rhode Island and Providence Plantations at the End of the Century: A History. Vo1. I. Boston: The Mason Publishing Company, 1902.

Peck, Reginald E. Early Land Holders of Watch Hill. Westerly: The Utter Company, 1936.

\section{Newspapers}

The Narragansett Weokly. Westerly, R. I. $1855-1866$. The Westerly Sun. Westerly, R. I. September 28, 1902 and February 18, 1926.

\section{Public Records}

Annual Report of the Adjutant General of the State of Rhode Island and Providence Plantations, for the Year 1865. A Report Prepared by Brigadier-General Elisha Dyer. 2 vols. Providence: E. I. Freemen \& Son, 1893-1995.

Record of Service of Connecticut Men in the Army and Navy of the United States During the War of the Rebellion. Complled by Authority of the General Assembly. Hartford: Case, Lockwood and Brainard Company, 1889. 
Town of Westerly. Tax Book. 1853-1866.

- Counc1l Records. Westerly, R. I. No. 7. 1860-1865.

- Town Meeting Recoràs. Westerly, R. I. No.8 Commencing 1855.

Westerly Rifles. Charter and Records of the Westerly Rifles. Located in the Westerly Public Library. - Minutes of the Westerly Rifles. Located in the Westerly Public Library. - Roster-Westerly Rifles. Located in the Westerly Public Library.

\section{Onpublished Material}

Pendleton, Albert P. "Westerly in the Fifties." Unpublished manuscript in the Local History file in the Westerly Public Library.

Zambarano, A. I. TThe Effect of the Civil War on South Kingstown." Onpublished History report, Department of History, University of Rhode Island, 1951. 